Magyar Honvédség Egészségügyi Központ Védelem Egészségügyi Igazgatóság

Pszichológiai és Egészségmagatartási Intézet Egészségfejlesztési Osztály ${ }^{1}$

Testnevelési Egyetem, Doktori Iskola ${ }^{2}$

Nemzeti Közszolgálati Egyetem, Hadtudományi Doktori Iskola

\title{
A túlsúly és az elhízás mozgásterápiás és étrendi kezelésének lehetősége a Magyar Honvédségben
}

\author{
Novák Attila ${ }^{1,2}$ százados, \\ Rázsó Zsófia ${ }^{1,3}$ hadnagy, \\ Kenessey Fanni ${ }^{1}$ százados
}

Kulcsszavak: elhízás, mozgásterápia, étrendi kezelés, Honvéd Testalkati Program, testalkati ajánlás

\begin{abstract}
A témaválasztás a hazai adatokat figyelembe véve még mindig aktuális, és tekintettel a trendre valószínüleg a hatékony intervenció hiányában az is marad. Az OTÁP 2014. vizsgálatok rámutattak arra, hogy a magyarországi felnőtt lakosság 65\%-a túlsúlyos vagy már elhízott [1]. Az elhízással összefüggő krónikus betegségek kialakulása súlyos terhet jelent nemcsak az egyénre, de a megváltozott munkaképesség miatt a társadalomra is. A túlsúly és az elhízás problémaköre a Magyar Honvédségben is tetten érhetö, ennek kezelésére a jogszabályban meghatározott Honvéd Testalkati Program keretében a személyi állománynak is lehetôsége nyílik. A Program egyik résztvevőjének esettanulmánya alapján mutatjuk be a mozgásterápiás és étrendi kezelések hatását a testalkati mutatók megváltozására.
\end{abstract}

\section{A túlsúly és az elhízás epidemiológiája, egészségügyi kockázatai}

A felnőtt magyar lakosság 1988. óta „terebélyesedik". A túlsúlyos, elhízott emberek száma 1988-ban még „csak” a lakosság 55\%-a volt, számuk azonban 2009. évre 62\%-ra, míg 2014. évre 65\%-ra emelkedett. Különösen a magasabb egészségügyi kockázattal járó elhízott kategóriákba lévők száma emelkedett több, mint duplájára [1]. A fejlett országok mindegyikében megfigyelhető ez a jelenség, ami a felborult energia egyensúllyal magyarázható. A „GLOBESITY” mára már egy világméretü járványnak tekinthető. Az elhízás gyógyíthatatlan, recidiváló, krónikus betegség „néma járvány” és a legnagyobb veszélye, hogy a betegségtudat nem alakul 
ki csak évtizedek múlva [2]. Miközben az 1960-as években a napi étkezés egy före jutó energia fogyasztás $2250 \mathrm{kcal}$ volt, addig 2005-ben már elérte a 2800 kcal-t [3]. A motorizáció széleskörü elterjedése a mindennapi fizikai aktivitás szintjét jelentősen csökkentette, ezzel párhuzamosan sajnos hazánkban is csökkenő tendenciát mutat a fizikai aktivitást rendszeresen végzők száma. A KSH időmérlegének vizsgálata alapján az úgynevezett „aktívak" a szabadidejüket nem sporttal vagy testmozgással töltik, inkább valamilyen fizikailag nem megterhelő tevékenységet részesítenek elönyben.

Az elhízással összefüggő megbetegedések, kórós állapotok, rizikótényezők száma növekvő tendenciát mutat, melynek egyik legsúlyosabb következménye a szív és érrendszeri megbetegedésekben jelentkezik. Erőteljes összefüggést találtak az elhízás és az ischaemiás szívbetegség kialakulása, pangásos szívelégtelenség, magas vérnyomás, kóros koleszterinszint kialakulása között. [4, 5] Számos endokrinológiai és emésztőrendszeri megbetegedés - cukorbetegség, gasztroözofagális refluxbetegség, a máj nem alkoholos zsíros elfajulása, epekövesség elöfordulási gyakorisága is nő az elhízott emberek között $[5,6]$. Ide sorolandók a neurológiai súlyos állapotok is - agyi érkatasztrófa, meralgia paresthetica, migrén, csuklótáji alagút szindróma, demencia, idiopátiás intrakraniális magas vérnyomás, sclerosis multiplex - melyek szintén gyakrabban fordulnak, elő az ideálisnál magasabb testtömeg indexszel (BMI) rendelkezők körében $[5,7,8,9,10,11$, 12]. A mozgásszervi problémák - köszvény, mozgáskorlátozottság, csont-ízületi gyulladás, derékfájás - megjelenését is nagymértékben befolyásolja a testsúly többlet $[5,13,14,15]$.
Az elhízás, a nagyobb testsúly az idő függvényében relatív magasabb halálozási kockázatot jelent. A nőknél a normál (20-24,9 BMI), a férfiaknál a sovány (18,5-19,9 BMI) és a normál testtömeg index (20-24,9 BMI) kategóriákban van a legkisebb halálozási kockázat [16]. Magyarországon a 19-64 évesek 11\%-a megváltozott munkaképességü, ami a legmagasabb előfordulási arány Európában. Az összes megváltozott munkaképességü 80\%-a a 45-64 évesek közül kerül ki. Az okok között első helyen, több, mint 30\%-os arányban, a mozgásszervi megbetegedések, míg másodikként a keringési megbetegedések vannak megjelölve, melynek hátterében többek között az elhízás is áll [17].

Tekintettel arra, hogy a nemzetközi és a magyar haderőnél is a civil populációból történik a szerződéses állomány toborzása, a NATO állományában is tetten érhető a túlsúly és az elhízás problémája, jelentős kihívást okozva ezzel, mind szervezeti (pl.: helyettesítések megszervezése, egészségügyi szabadság kifizetése), mind egyéni (pl.: szolgálatra való képtelenség korai megjelenése, egészségügyi szabadságon töltött idő) szinten (1. ábra). A honvédség keretein belül kiemelten fontos a fizikai állóképesség és a harcképesség fenntartása. A rendszeres sportmozgás, az egyik alapfeltétele az egészség megőrzésének. Annak élettani és pszichoszociális egészségre gyakorolt hatása nagyban hozzájárul a fizikális és mentális állóképesség fenntartásához, továbbá a szolgálatképes állapot és hadrafoghatóság hosszú távú megőrzéséhez.

A túlsúly és az elhízás prevalenciája leginkább Görögország és az USA haderejét érinti, összesen $43,7 \%$ és $45,4 \%$ os előfordulási arányban, legkevésbé pedig Lengyelország hadserege érintett, összesen 14,31\%-os gyakorisággal. 


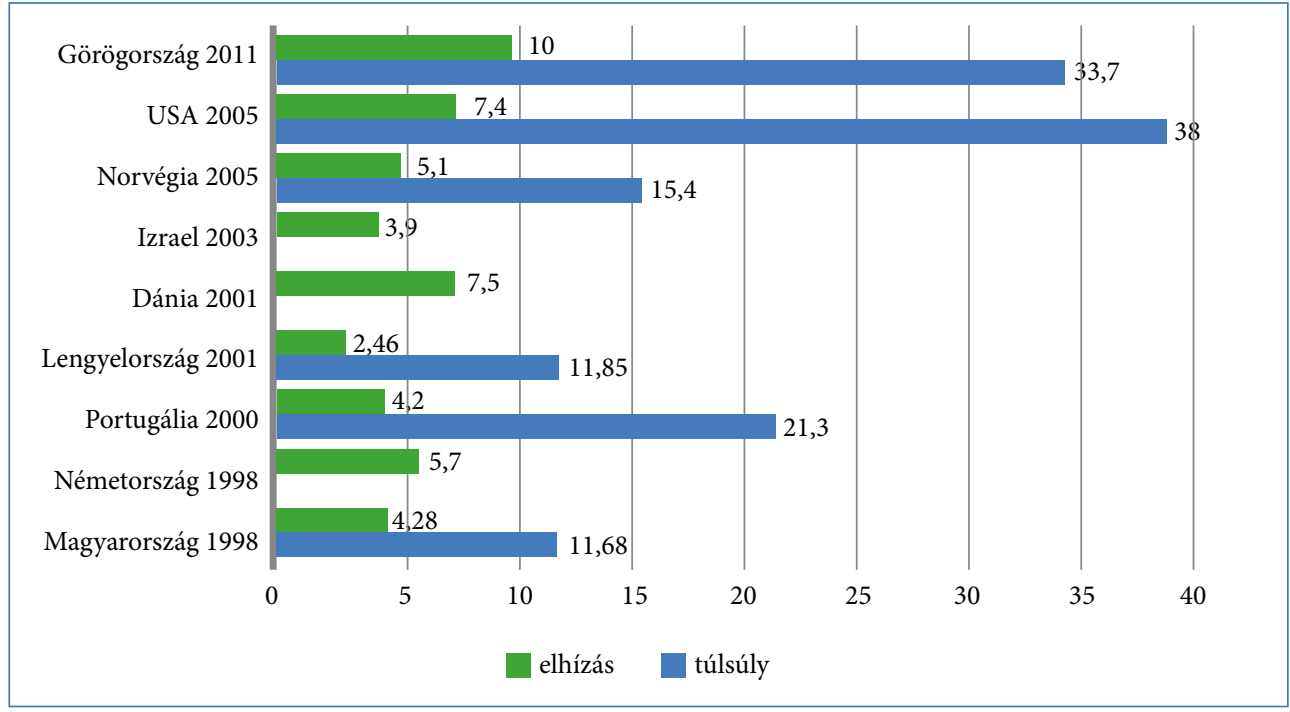

1. ábra. A túlsúly és az elhízás gyakorisága (\%) néhány NATO tagállam, valamint Izrael sorkötelesei között [18]

Az életkor elöre haladtával is egyre nagyobb arányban jelentkezik a túlsúly és az elhízás. A kötelező éves fizikai állapotfelmérések során detektálható volt, hogy bármelyik mozgásformában felmért katonák - a keringési és állóképességi, valamint az izomerő állóképességi gyakorlatoknál - az egészségesnek számító 20-24,9 közötti normál BMI-vel rendelkezők nyújtották a legnagyobb teljesítményt, minden korosztály esetében. A testzsír tekintetében, már közel az ideális sportolói szintü, 13-17\%-kal rendelkezőknek volt a legnagyobb teljesítményük [18]. Az elhízás terápiás lehetőségei aszerint változnak, hogy milyen súlyossági fokú az elhízás, az életstílus megváltoztatása azonban mindegyik esetében alapvető kívánalom [19]. Az életmód két alapvető pillére a táplálkozás és a fizikai aktivitás. A megfelelő mennyiségü és minőségü mozgás kedvező hatásai nem kérdőjelezhetők meg az elhízással kapcsolatban, csakúgy, mint a megfelelö minőségü és mennyiségü táplálkozás sem: csökken a zsírszövet mennyisége, nő az izom- és a csonttömeg [20]. Mérséklődik a testtömeg-csökkenés által előidézett nyugalmi anyagcsere visszaesés [21]. Továbbá csökken a vérnyomás, javul a glükóz tolerancia, az inzulin szenzitivitás es a lipid profil [19]. Javul a fizikai teljesítőképesség. Nő az elkötelezettség a diéta hosszú távú fenntartására [19]. Jobb közérzetet biztosít, javítja az önbecsülést, csökkenti a feszültséget és a depresszió kialakulásának lehetőséget [17].

Az ember testsúlyának befolyásolása egy bonyolult folyamat, amelyben meghatározó jelentőséggel bír egy szabályzási pont (set point), amely elnevezésével ellentétben nem egy pont, hanem egy tartomány, ami $+/-4,5-7$ kg közötti változást jelenthet. Életstílusunk hatással van testtömegünkre, azonban az előbbiekben említett tartomány határértékein kívül maradni nehéz, legyen szó akár fogyásról vagy hízásról. Agyunk a testsúlyunk $10 \%$-át meghaladó súlyvesztést éhezésként kezeli, attól függetlenül, hogy az illető sovány vagy túlsúlyos/elhízott. 
I. táblázat. A túlsúly és az elhizás kezelésének szakmai és szervezeti irányelvei

\begin{tabular}{|c|c|c|c|}
\hline \multicolumn{4}{|c|}{ TERÁPIÁS LEHETÖSÉGEK BMI ÉS HASKÖRFOGAT SZERINT } \\
\hline BMI, $\mathrm{kg} / \mathrm{m}^{2}$ & $\begin{array}{l}\text { haskörfogat, } \mathrm{cm} \\
\text { férfi< }<94, \text { nö<80 }\end{array}$ & $\begin{array}{l}\text { haskörfogat, } \mathrm{cm} \\
\text { férfi } \geq 94, \text { nő } \geq 80\end{array}$ & kísérőbetegségek \\
\hline $\begin{array}{l}25,0-29,9 \\
30,0-34,9 \\
35,0-39,9 \\
\geq 40\end{array}$ & $\begin{array}{c}\dot{E} \\
\dot{E} \\
\dot{E}+G Y \\
E+G Y+S\end{array}$ & $\begin{array}{c}\dot{E} \\
\dot{E}+G Y \\
\dot{E}+G Y \\
\dot{E}+G Y+S\end{array}$ & $\begin{array}{c}\dot{E}+G Y(B M I: 27,0-29,0) \\
\dot{E}+G Y \\
\dot{E}+G Y+S \\
\dot{E}+G Y+S\end{array}$ \\
\hline \multicolumn{4}{|c|}{$\begin{array}{l}\text { É = életmód változtatás (étrend és fizikai aktivitás) } \\
\mathrm{GY}=\text { gyógyszeres kezelés megfontolása } \\
\mathrm{S}=\text { sebészeti kezelés megfontolása }\end{array}$} \\
\hline$A M$ & ógiai és Mozgáste & ársaság állásfoglala & s ajánlása (2012) \\
\hline
\end{tabular}

A testsúly változásával az alapanyagcsere is változik, az ember alapanyagcseréjének oxigén igénye $1 \mathrm{MET}$, ami testsúly kilogrammonként megközelítőleg 3,5 ml oxigén felhasználást jelent percenként. Ez az érték az életkor előrehaladtával egyre nagyobb mértékben csökken. A vizsgálatok azt mutatják, hogy a kalória bevitel korlátozása nélkül 13-26 metabolikus ekvivalens (MET) óra/hét mennyiségü fizikai aktivitás kell a metabolikus paraméterek javulásához, illetve az össz-zsír és az abdominális zsír ${ }^{1}$ mennyiség mérséklődéséhez, csökkenéséhez. Ez hetente 150 perc $5,4 \mathrm{~km} / \mathrm{h}$ sebességgel végzett gyaloglásnak vagy 75 perc $8 \mathrm{~km} / \mathrm{h}$ sebességü kocogásnak felel meg [19]. Az állóképességi munkát mindenképpen ki kell egészíteni rezisztencia edzéssel. A rezisztencia edzés olyan gyakorlatok összességét jelenti, melyek során az izmok összehúzódását úgynevezett „külső ellenállással” fokozzuk. Ezt a külső ellenállást kiválthatják például súlyzók, vizes palackok, stb.

1 A belső szervek között lerakódó zsírt nevezzük zsigeri vagy más néven viszcerális zsírnak is - ami elhelyezkedéséböl fakadóan - a belső szervek közelében található, ezért felszaporodása különösen megnöveli bizonyos betegségek kockázatát, valamint könnyebben aktiválódik az úgynevezett lipoprotein lipáz enzim. használatával [21]. Akik fele-fele arányban alkalmazták az állóképességi edzést és a rezisztencia edzést, sokkal hatékonyabban tudtak a súlyukból veszíteni úgy, hogy nem csökkent az izomtömegük - ami a fogyás egyik nehezen kiküszöbölhető velejárója - mint azok, akik csak állóképességi edzést végeztek [22].

$\mathrm{Az}$ elhízás mozgásterápiás kezelésének folyamatában erős motivációra van szükség, amely az életkorral jelentős változáson megy keresztül. Ennek tudatában kell kialakítani a mindennapi megfelelő fizikai aktivitásra való igényt. Saját kutatásaink azt mutatják, hogy az idősebb korosztálynál egyre inkább elötérbe kerül az egészségre való törekvés abban, hogy testmozgást végezzenek. Ellenben a fiatalabb korosztálynál a mozgásra, sportolásra való késztetést a fizikai erő növelése és az esztétikus külső megjelenés hajtja. A sportmotivációs tényezők nem csak életkorfüggők, hanem a saját edzettségi állapot megítélésével is változnak. Azon személyek, akik elégedettebbek saját edzettségi állapotukkal, azoknál a sportolás élvezete, mint motivációs tényező az első helyen szerepel. Ugyanez mondható el azokról, akik kielégítőnek értékelik a saját fizikai teljesítő képességük állapotát. Akik azonban elégedetlenek magukkal ezen a téren, 
azoknál az egészség megtartása, illetve a betegségek elkerülése szerepel az első helyen. Érdekes módon mindhárom kategóriában a versengést, a közösség elismerését tették az utolsó helyre, mint motivációs hajtóerőt.

\section{A túlsúly és az elhízás kezelésének lehetősége a Magyar Honvédség állománya körében}

A felnőttkori elhízás a katonai szolgálat alatt nemcsak esztétikai probléma (a katonás megjelenést rontja), hanem számos betegség kialakulását elősegítő rizikófaktor, amely ma már önálló betegségként is definiált. A túlsúly és az elhízás megoldására új honvéd-egészségügyi képességként bevezetett Honvéd Testalkati Program (HTP) kínál lehetőséget, amely „A katonai szolgálatra való egészségi, pszichikai és fizikai alkalmasságról, valamint felülvizsgálati eljárásról" szóló 10/2015. (VII.30.) HM rendelet (Rendelet) határoz meg. A Rendelet testalkati ajánlásokat tartalmaz, úgymint a minimálisan és maximálisan ajánlott testtömeg korosztályonként, a testmagasság függvényében, a minimálisan és maximálisan ajánlott testzsírszázalék korosztályonként és az ideális BMI érték. A HTP célja lehetőséget biztosítani és támogatást nyújtani a testalkati követelményektől eltérő mutatókkal rendelkező honvédek számára a testsúly (testzsír) csökkentésére 12 hónap időtartamban és nem utolsó sorban térítésmentesen.

A honvédek testalkati mutatóinak monitorozása a Magyar Honvédség alakulatainál egységesen OMRON BF 511 müszerrel történik, amely rendelkezésre áll mind a csapategészségügyi szolgálatoknál, mind pedig a testnevelő szakember állománnyal rendelkező kiképzésért felelős szervezeti egységeknél. A HTP- be való jelentkezés történhet egyrészről a honvéd saját elhatározása és egyéni motivációs tényezői alapján, másrészről a megmért testösszetételi eredményeket a Rendeletben szereplő testösszetételi ajánlásokkal összevetve - a csapatorvosnak és/vagy a testnevelö szakembernek fel kell hívni a figyelmet a HTP-ben való részvétel lehetőségére. $\mathrm{A}$ részvétel $\mathrm{ez}$ utóbbi esetben is önkéntes.

\section{Az egyéni étrendi kezelés és a mozgásterápia bemutatása}

A HTP egyénre szabottan, a résztvevő igényeinek, a személyes céljainak és az aktuális fizikai és egészségi állapot alapján kerül kialakításra. Az egyéni igények figyelembe vételéhez szükséges komplex szemléletet és intervenciós lehetőségeket egy, a HTP-ben résztvevő kliens eredményei alapján ismertetjük. Esettanulmányunk során bemutatunk egy 36 éves 182 centiméter magas 108,8 kilogramm testtömegü férfit, $\quad\left(B M I=32,8 \quad \mathrm{~kg} / \mathrm{m}^{2}\right)$, aki 3 éve elhízott. OMRON BF 511 testösszetétel mérő készülékkel megmértük a testzsír százalékát, melynek alapján a testének 33,2\%-a zsír volt. A derék-csípő méretaránya 1,06 volt a kiindulási állapotnál. Többször próbálkozott testsúly csökkentéssel, sikertelenül. Enyhe, időszakosan előforduló hipertóniát állapítottak meg nála, melynek kezelésére életmód változtatást javasoltak. Fizikai terhelésre mozgásszervi panaszokat említett mindkét boka, illetve térd tájékon. Aktív dohányos, naponta körülbelül 20 szál cigarettát szívott el. Táplálkozással öszszefüggő panaszai között az időszakosan előforduló gyomorsav túltengés szerepelt, mely tünetet rágótablettával csillapította. $\mathrm{Az}$ élelmiszerfogyasztási gyakorisági kérdőív alapján a kiegyensúlyozott és vegyes táplálkozás jellemezte, amelyet 3 fö- és 


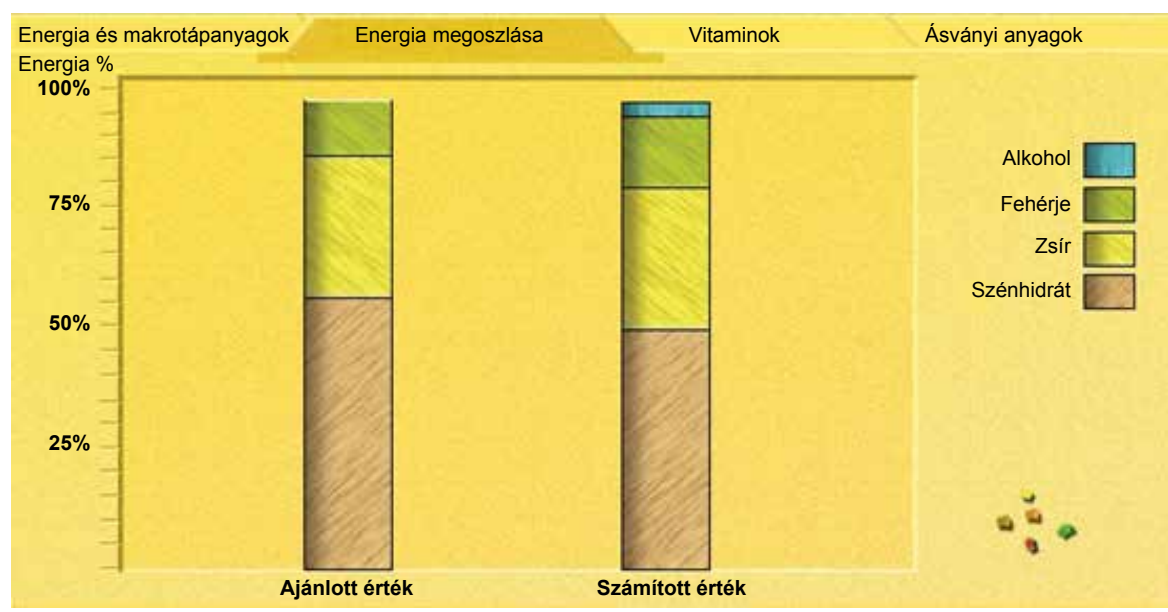

2. ábra. A bevitt energia megoszlása

1 kisétkezés során biztosított. A Nutricomp Étrend és Tápanyagszámító Program segítségével értékeltük a 3 napos táplálkozási naplóját, melynek eredményeit a 2., 3., 4. és 5. ábrán mutatunk be.

$\mathrm{Az}$ 2. ábrán látható a bevitt energia makrotápanyagok szerinti megoszlása, az ajánlott értéket hasonlítva a számított értékhez. Látható a mérsékelt alkohol fogyasztás és a fehérjedús táplálkozás, továbbá, hogy a zsírok és a szénhidrátok beviteli arányában nincs lényeges különbség az ajánlott és a számított értékekhez képest.
A 3. ábrán bemutatjuk az energia és makrotápanyagok beviteli értékének jellemzőit az optimalizált 100\%-hoz képest. A zöld színű tartomány $+/-30 \%$-os eltérést mutat, mely táplálkozás egészségügyi szempontból elfogadhatónak minősül. (A piros színü tartományban $-30 \%$ alatti, azaz elégtelen beviteli értékek jelennek meg, míg a sárga zónában a $+30 \%$ fölötti, azaz a túlzott beviteli értékek mutatkoznak). Az adott személy esetében mérsékelt energia bevitel, fehérje- és élelmi rostban dús táplálkozás, valamint elegendő zsír, szénhidrát és koleszterin fogyasztás jellemző.

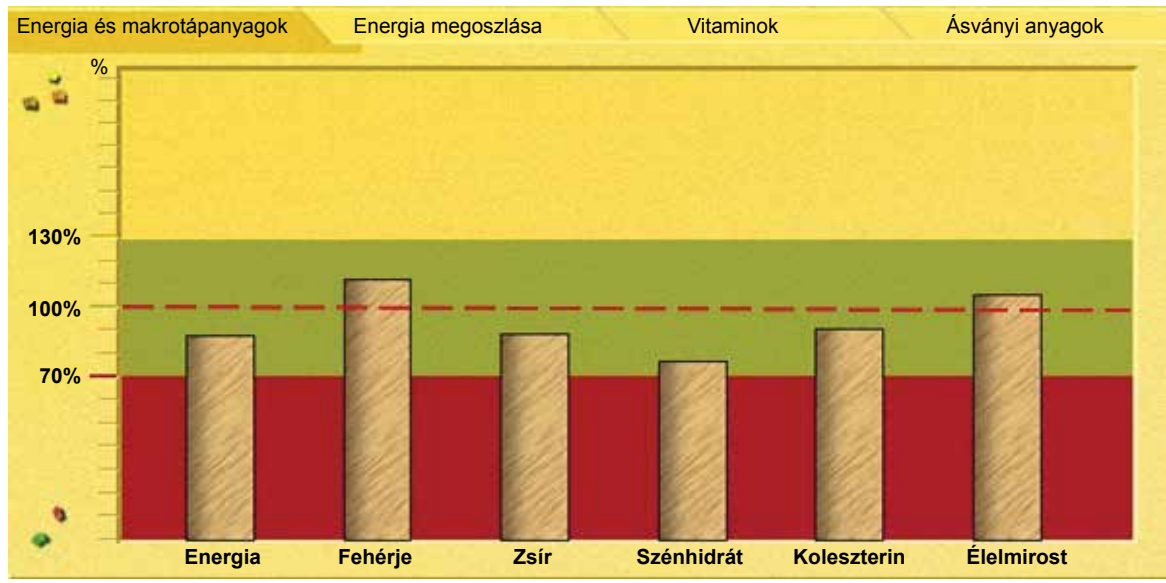

3. ábra. Az energia és makrotápanyagok beviteli értéke 


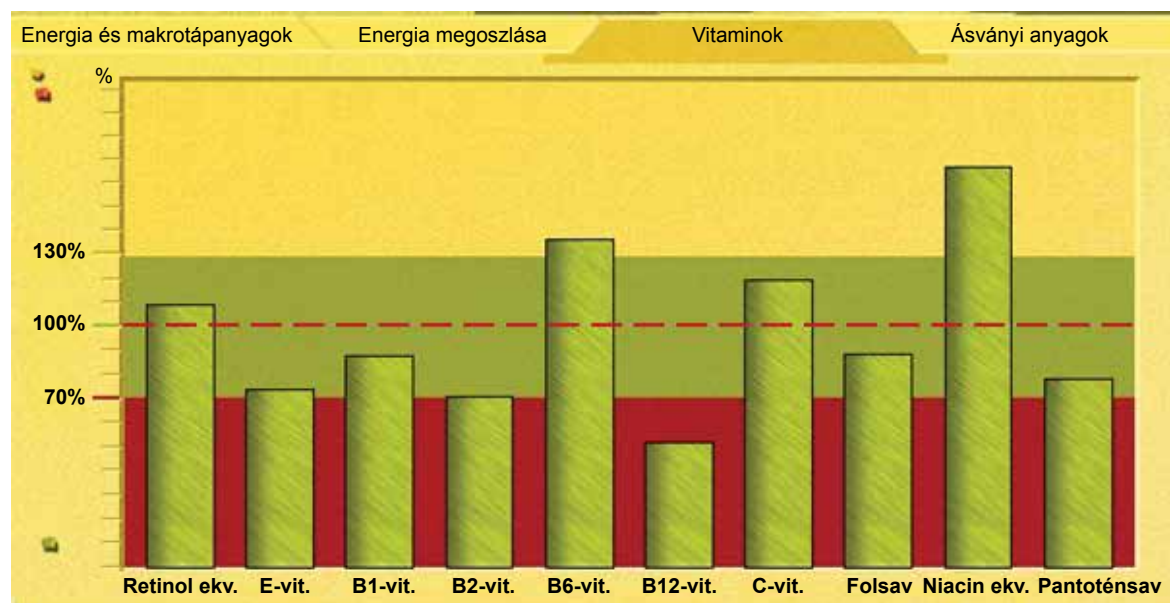

4. ábra. A vitaminok beviteli értéke

A 4. ábrán látható a vitaminok beviteli érték jellemzői az optimalizált 100\%-hoz képest. A piros színü tartományban -30\% alatti, azaz az elégtelen beviteli értékek jelennek meg, ebben az esetben a B12 vitamin. Az elfogadható beviteli értéknél a $\mathrm{B} 2$ vitamin látható, míg a sárga zónában a $+30 \%$ fölötti, azaz a túlzott beviteli értékek mutatkoznak, a B6 vitamin és a niacin ekvivalens (B3 vitamin) szempontjából. A többi zsírban és vízben oldódó vitamin a zöld színű tartományban szerepel, amely táplálkozás egészségügyi szempontból elfogadhatónak minősül.
$\mathrm{Az}$ 5. ábrán bemutatjuk az ásványi anyagok beviteli értékének jellemzöit az optimalizált $100 \%$-hoz képest. A piros színű tartományban $-30 \%$ alatti, azaz elégtelen beviteli érték jelenik meg, mint a kalcium és a cink. A sárga zónában a $+30 \%$ fölötti, azaz a túlzott beviteli értékek mutatkoznak a nátriumra és a foszforra nézve. A kálium, a magnézium, a vas és a réz a zöld színű tartományban szerepel, amely táplálkozás egészségügyi szempontból elfogadható.

A 6. ábrán az élelmiszer piramishoz való hasonlítás látható, ami a napi

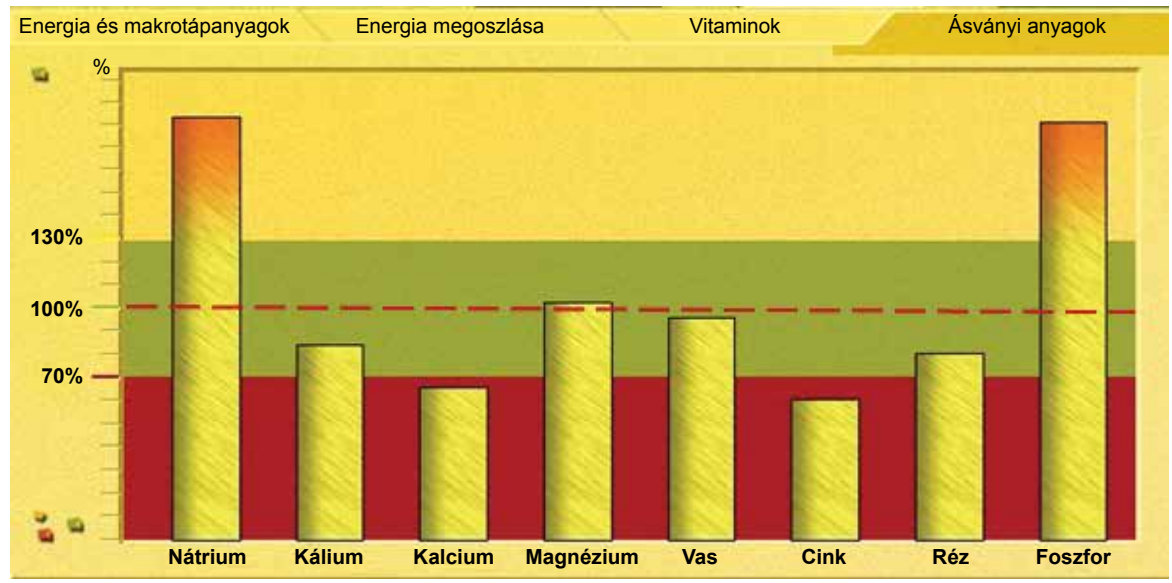

5. ábra. Az ásványi anyagok beviteli értéke 


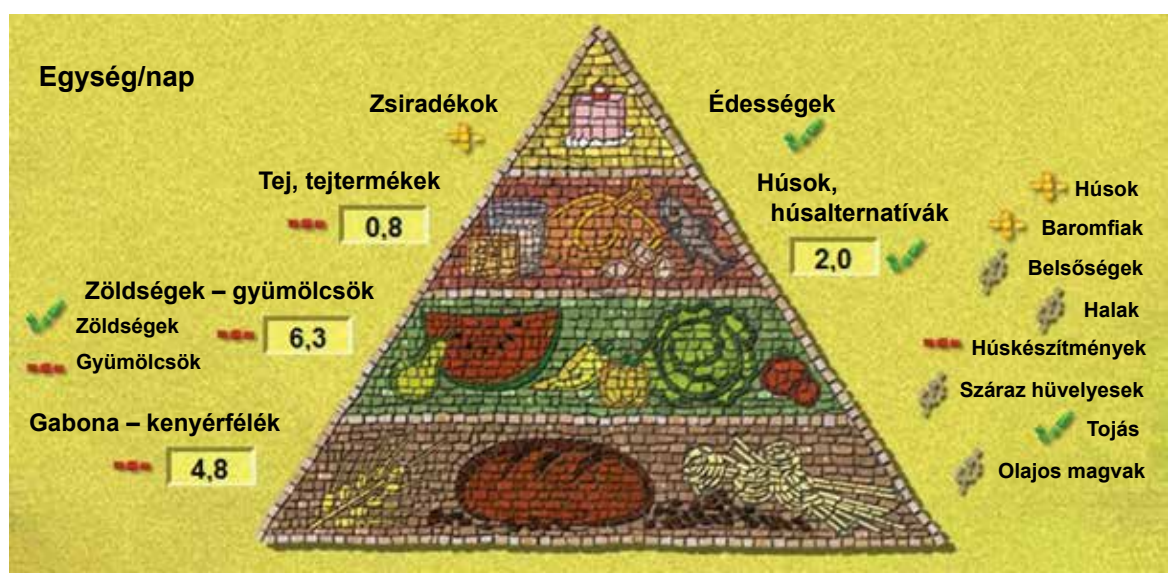

6. ábra. Az élelmiszer piramishoz való hasonlitás

piros színü vízszintes vonal $(-)=$ elégtelen beviteli érték sárga színủ plusz jel $(+)=$ többlet beviteli érték zöld színü pipa $(\checkmark)=$ elegendő beviteli érték

szürke színű átlósan áthúzott nulla jelzés $(\varnothing)=$ az adott élelmiszer csoport hiánya

rendszerességgel fogyasztott egyes élelmiszercsoportok adagmennyiségét (pl. gabona-kenyérfélék: 4,8 adag/nap) hasonlítja a szoftver által számolt ajánlott beviteli értékekhez. Az ábra alapján elmondható, hogy a tej, és tejtermékek, a gyümölcsök, a gabonafélék bevitele kevésnek mutatkozott, a húskészítményekből, a zsiradékokból, a húsokból és a baromfi-félékből többlet jelentkezett. Az édességek, a húsok és hús alternatívák, valamint a tojás napi bevitele elegendő volt. A táplálkozásból hiányoztak a belsőségek, a halak, a száraz hüvelyesek és az olajos magvak.

Összegezve a bemutatott ábrák alapján, a mérsékelt energia bevitel, a fehérjedús és élelmi rostban gazdag táplálkozás, elegendő szénhidrát és zsír fogyasztás, mérsékelt alkoholfogyasztás, tej és tejtermékek hiányos bevitele jellemezte a kliens táplálkozási szokásait. A délutáni kis étkezését édesség formájában biztosította. A folyadék fogyasztására jellemző volt a napi rendszerességü 3 liter víz és 0,5 liter gyümölcs ízesítésü sörök fogyasztása.

\section{Étrendi ajánlás}

A 3 napos táplálkozási napló elemzését és az egyéni igényeket figyelembe véve étrendi ajánlásokat fogalmaztunk meg: a detektált, mérsékelt energia bevitelt napi ötszöri elosztásban javasoltuk elfogyasztani. Erőteljes nátriumcsökkentést javasoltunk mind az ásványvíz, mind az ételízesítők területén, egyrészről alacsony nátrium tartalmú ásványvizek fogyasztásával, másrészről sómentes zöldfüszerek használatának bevezetésével. A gyorsan felszívódó szénhidrátokat javasoltuk kiváltani lassan felszívódó szénhidrátokkal, úgy, mint durumtészta, natúr zabpehely, zabkorpa fogyasztásával. Gyümölcsfogyasztás tekintetében a délelőtti kis étkezésre $1 \mathrm{db}$ alma fogyasztását ajánlottuk. Jó közérzetéhez a napi rendszerességü gyümölcsös sör elfogyasztása hozzájárult, ezért úgy építettük be az étkezési szokásaiba a mérsékelt alkohol fogyasztást, hogy mellette fél adag vacsora elfogyasztását javasoltuk. A táplálkozási ajánlás tehát elsősorban az adag nagyságokra, azaz mennyiségi korláto- 
zásokra, valamint a minőségi élelmiszerek bevezetésére fókuszált, így az alap/ nyugalmi anyagcsere értéke és jellemzői a tanácsadás során csak tájékoztató jellegüek voltak. Az étrend megváltoztatása a mozgásprogrammal kiegészítve az anyagcsere fokozódását eredményezi, ezért aktív napokon bőséges reggeli elfogyasztását javasoltuk, azaz a megszokott fótkezés mennyiségét kiegészíteni banánnal, müzli szelettel, mézzel.

$\mathrm{Az}$ egyéni tanácsadások során a táplálkozás mennyiségi és minőségi változásait nyomon követtük, kiegészítve olyan változtatásokkal, melyek a program alatt jelentkező egyéni igényeknek is megfeleltek. A 4 hónap alatt a kliens részéről pozitív visszajelzést kaptunk az élelmiszerek mennyiségére, minőségére és egyéni elégedettségére, ízlésére vonatkozóan. Sőt, érdeklődése kiterjedt az élelmiszerek jelölésére, ezért a tanácsadás során kapott ismeretek birtokában tudatosan válogatott az élelmiszerek közül mind a bevásárlása, mind pedig a munkahelyi étkezése során.

\section{Mozgásterápiás ajánlás}

Kezdetben gyaloglást, 30 percen keresztül fokozatosan növelt sebességgel (5 $\mathrm{km} / \mathrm{h}$-ról $6 \mathrm{~km} / \mathrm{h}$-ra) és 10 percen keresztül evezőpadon való evezést kellett végeznie. Az előbbi esetben 2700 métert, míg az utóbbi esetben 1800 métert tudott megtenni. A törzsizomzat fejlesztését célzó gyakorlatokat is beleszámítva összesen $201 \mathrm{kcal}$ volt az energia felhasználás. A következő 10 nap alatt 5 alkalommal hajtotta végre ezt az edzést. Ezután emeltük az intenzitást és a terjedelmet is: 10 perc eröltetett gyaloglás $6,4 \mathrm{~km} / \mathrm{h}$ sebességgel és 10 perc futás $9,2 \mathrm{~km} / \mathrm{h}$ sebességgel, összesen 2600 méter megtételére volt elegendő. Továbbá az evezőgépen 15 perc alatt 2900 métert tett meg. Ezt követően törzsizomzat fejlesztő gyakorlatokat végzett 10 percen keresztül. Mindösszesen közel $350 \mathrm{kcal}$ volt az energia felhasználása. Ezt a mozgásformát a következő 7 nap alatt három alkalommal végezte el. Az utolsó változtatást ez után alkalmaztuk, amikor bemelegítés után 20 perc alatt $3 \mathrm{~km}$ es távot tett meg, majd az evezögépen 15 perc alatt $3,1 \mathrm{~km}$-t, végül a törzsizom erösítő gyakorlatokat 10 perc alatt végezte el. Ezekkel összesen mintegy $470 \mathrm{kcal}$ energia felhasználás jellemezte. A testalkati mutatók változásait havi rendszerességgel követtük, mely változásokat a II. táblázat tartalmazza.

A II. táblázatban látható, hogy a kiindulási és a harmadik hónapot követő 4. kontroll során mért testalkati mutatók kedvezöen változtak: a testtömeg csökkent $6,2 \mathrm{~kg}$-mal, a BMI csökkent $1,8 \mathrm{~kg} / \mathrm{m}^{2}$ értékkel, a testzsír százaléka mérséklődött 2,6\%-kal. A derék körfogata csökkent $7 \mathrm{~cm}$-rel, a csípő körfogata azonban

II. táblázat. Testalkati mutatók változása a rendszeres mozgás hatására

\begin{tabular}{|l|c|c|c|c|}
\hline Alkalom & 1. & 2. & 3. & 4. \\
\hline Testtömeg (kg) & 108,8 & 106,5 & 104,5 & 102,6 \\
\hline BMI & 32,8 & 32,2 & 31,5 & 31 \\
\hline Testzsír (\%) & 33,2 & 32,6 & 31,7 & 30,6 \\
\hline Derék körfogat (cm) & 119 & 115 & 117 & 112 \\
\hline Csípő körfogat (cm) & 112 & 112 & 115 & 115 \\
\hline Derék/csípő méretarány & 1,06 & 1,02 & 1,01 & 0,97 \\
\hline
\end{tabular}


emelkedett $3 \mathrm{~cm}$-rel, mely eredmények tükrében a derék/csípö méretaránya is mérséklődött.

Összegzésként elmondható, hogy az elhízási tendencia a Magyar Honvédséget is érinti. Az elmúlt években a miszszióra jelentkező állomány körében az egészségi szempontból alkalmatlan minősítések 20-25\%-ának hátterében az életmóddal és táplálkozással összefüggő vagy befolyásolható okok álltak (pl. elhízás, magas vérnyomás) [23]. A testsúlyunk függ attól, hogy mennyi energiát viszünk be, és mennyi energiát használunk el. Az emberek többsége nem veszi figyelembe, hogy az éhséget, és az energiafelhasználást is az agy irányítja: túlnyomóan a tudtunk nélkül. Agyunkban megvan, hogy mi a megfelelö súly számunkra, a tudatos véleményünktől függetlenül. $\mathrm{Ha}$ a testsúlyvesztés több, mint 10\%, akkor 250-400 kilokalóriával kevesebbet fog az illető felhasználni naponta, mert anyagcseréje lelassul. Evolúciós szempontból ez a reakció a súlyvesztésre teljesen érthetö. Öseink túlélése az energiatakarékosságon múlt, amikor kevés volt a táplálék, súlyuk visszanyerése volt a cél. Az emberi történelem során az éhezés sokkal nagyobb probléma volt, mint a túlevés ez lehet a magyarázat arra, hogy szabályozási pontunk felfelé mehet, de lefelé ritkán. Az elhízással kapcsolatos krónikus betegségek mozgásterápiás és étrendi kezelésének elsődlegesen a testsúly rehabilitációt kell szolgálniuk. A már kialakult idült betegségek jelentős mértékben befolyásolják a mozgásterápiás lehetőségeket, a kor, a nem és a fizikai állapot mellett. Az étrendi kezelés esetében is kiemelkedő jelentőségü az egyéni táplálkozási szokások mellett, a táplálkozással összefüggő betegségek ismerete is.

\section{Irodalom}

[1] Országos Táplálkozási és Tápláltsági Állapot Vizsgálat, 2014. https://www.ogyei.gov.hu/ otap_2014/

[2] Global, regional and natoinal prevalence of overweight and obesity in children and adults during 1980-2013: A systematic analysis for the Global Burden of Disease Study, 2013. http://www.thelancet.com/journals/lancet/ article/PIIS0140-6736(14)60460-8/abstract DOI: $10.1016 / S 0140-6736(14) 60460-8$

[3] Earth Trends: Nutrition: Calorie supply per capita. World Resources Institute http://pdf. wri.org/world_resources_2008_roots_of_ resilience_tables.pdf

[4] Yusuf, S., Hawken, S., Ounpuu, S. et al.: INTERHEART Study Investigators. Effect of potentially modifiable risk factors associated with myocardial infarction in 52 countries (the INTERHEART study): Case-control study. Lancet, 2004, 364 (9438): 937-52. DOI: 10.1016/S0140-6736(04)17018-9

[5] Haslam, D.W., James, W.P.: Obesity. Lancet, 2005, 366 (9492): 1197-209.

DOI: 10.1016/S0140-6736(05)67483-1

[6] Anand, G., Katz, P.O.: Gastroesophageal reflux disease and obesity. Rev. Gastroenterol. Disord., 2008, 8 (4): 233-9.

[7] Harney, D., Patijn, J.: Meralgia paresthetica: diagnosis and management strategies. Pain Med., 2007, 8 (8): 669-77. DOI: $10.1111 /$ j.1526-4637.2006.00227.x

[8] Bigal, M.E., Lipton, R.B.: Obesity and chronic daily headache. Curr. Pain Headache Rep., 2008, 12 (1): 56-61.

DOI: $10.1007 / \mathrm{s} 11916-008-0011-8$

[9] Sharifi-Mollayousefi, A.: Assessment of body mass index and hand anthropometric measurements as independent risk factors for carpal tunnel syndrome. Folia Morphol. (Warsz), 2008, 67 (1): 36-42.

[10] Beydoun, M.A., Beydoun, H.A, Wang, Y.: Obesity and central obesity as risk factors for incident dementia and its subtypes: A systematic review and meta-analysis. Obes. Rev., 2008, 9 (3): 204-18. DOI: 10.1111/j.1467-789X.2008.00473.x.

[11] Wall, M.: Idiopathic intracranial hypertension (pseudotumor cerebri). Curr. Neurol. Neurosci. Rep., 2008, 8(2): 87-93. 
[12] Munger, K. L., Chitnis, T., Ascherio, A.: Body size and risk of MS in two cohorts of US women. Neurology, 2009, 73 (19): 1543-50. DOI: 10.1212/WNL.0b013e3181c0d6e0

[13] Choi, H.K., Atkinson, K., Karlson, E.W., Curhan, G.: Obesity, weight change, hypertension, diuretic use, and risk of gout in men: the health professionals follow-up study. Arch. Intern. Med., 2005, 165 (7): 742-8. DOI: 10.1001/archinte.165.7.742

[14] Tukker, A., Visscher, T., Picavet, H.: Overweight and health problems of the lower extremities: osteoarthritis, pain and disability. Public Health Nutr., 2008, 12 (3): 1-10. DOI. 10.1017/S1368980008002103.

[15] Molenaar, E.A., Numans, M.E., van Ameijden, E.J., Grobbee, D.E.: Considerable comorbidity in overweight adults: results from the Utrecht Health Project. Ned. Tijdschr. Geneeskd, 2008, 152 (45): 2457-63.

[16] Berrington de Gonzalez, A.: Body-Mass Index and Mortality among 1.46 Million White Adults". N. Engl. J. Med., 2010, 363 (23): 2211-9. DOI: 10.1056/NEJMoa1000367

[17] Munkaerőpiaci helyzetkép, 2015., Központi Statisztikai Hivatal 2016. október https:// www.ksh.hu/docs/hun/xftp/idoszaki/ munkerohelyz/munkerohelyz15.pdf

[18] Juhász Zs.: A magyar katonák külföldi katonai szolgálatra történő fizikai alkalmasságvizsgálatának tapasztalatai, Doktori $(\mathrm{PhD})$ értekezés, Zrínyi Miklós Nemzetvédelmi Egyetem Bolyai János Hadmérnöki Kar, Hadmérnöki Doktori Iskola, 2011.

[19] Simonyi G., Pados Gy., Bedros J. R. (szerk.): Az elhízás kezelésének szakmai és szervezeti irányelvei, A Magyar Obezitológiai és Mozgásterápiás Társaság állásfoglalása és ajánlása, 2012.

[20] Kay, S.J., Fiatarone Singh, M.A.: The influence of physical activity on abdominal fat: a systematic review of the literature. Obes. Rev., 2006, 7:183-200. DOI: 10.1111/j.1467-789X.2006.00250.x

[21] Kedvesné Kupai K.: Rezisztencia edzés. In: Kedvesné Kupai K.: Teljesítményfokozás lehetséges és tiltott eszközei. Szeged: SZTE, [s. a.] http://www.jgypk.hu/tamop13e/ tananyag_html/tananyag_teljesitmenyfokozas/18_rezisztencia_edzs.html
[22] Westcott, W.: Strength training 201. Fitness Management, 1997, 13(7): 33-35.

[23] Novák A., Sótér A., Rázsó Zs., Juhász Zs.: Harc az elhízás ellen, Honvédségi Szemle, 2017, 145 (3): 74-86.

\section{Capt. Attila Novák, \\ Lt. Zsófia Rázsó, \\ Capt. Fanni Kenessey,}

\section{The opportunity of excercise therapy and dietetic guidelines of the obes-related chronic diseases}

The choice of subject is still relevant considering the Hungarian values and probably still remain in default of effective intervention in view of the trend. In 2014 Hungarian Food Safety Office performed that $65 \%$ of the Hungarian adult population is overweight or already obes. All of this on the grounds of obes-related chronic diseases development means a serious burden not only the individual but by the reason of the changing work ability the society also. The problem of the overweight and obes is detected within the Hungarian Defence Forces. Defined by law the Hungarian Army Body Composition Program what is available in order to the weight rehabilitaton for the military person. Introduce by the Program's members' positive effects on the physical changes by the excercise therapy and the dietetic guidelines.

Keywords: obesity, excercise therapy, dietetic guidelines, Hungarian Army Body Composition Program, physical requirements

Novák Attila százados 1134 Budapest, Róbert Károly krt.44. 